\title{
Kirjallisuutta
}

\section{Kasvatusfilosofian lähtökohtia}

Sirkka Hirsjärvi:

Johdatus kasvatusfilosofiaan

Kirjayhtymä, 1985, 219 s.

Maassamme harjoitettu kasvatustieteellinen tutkimus on viime aikoina joutunut eri tahoilta tulevan kritiikin kohteeksi. Eräät kriitikot katsovat, että kasvatustieteilijät näpertelevät pienten, ei kovinkaan merkityksellisten, mutta kvantatiivisesti tutkittavissa olevien ongelmien parissa kykemättä hallitsemaan teoreettisesti kasvatusilmiöitä kokonaisuudessaan. Tämä viittaa näiden kriitikkojen mielestä siihen, että kasvatustieteilijöillä on puutteellinen teoreettinen itseymmärrys omasta tieteenalastaan ja sen filosofisista perusteista. Toiset kriitikot ovat taas sitä mieltä, että kasvatustieteellisen tutkimuksen ja sen perustana olevien teorioiden ja käytännön kasvatustoiminnan välillä on liian suuri kuilu, eli kasvatustieteilijät eivät ota tutkimuksessaan riittävästi huomioon sitä kasvatustodellisuutta, jossa kasvattajat toimivat. Joka tapauksessa näyttää siis siltä, että kasvatustieteellisessä tutkimuksessa esiintyy perustavaa laatua olevia ongelmia, jotka pakottavat kasvatustieteilijät pohtimaan kriittisesti oman tieteenalansa ja tutkimuskäytäntönsä filosofisia perusteita ja kenties arvioimaan uudelleen kasvatustieteellisen tutkimuksen tavoitteet ja merkityksen kasvatukselle.

Tätä taustaa vasten Sirkka Hirsjärven Johdatus kasvatusfilosofiaan voidaan nähdä yhtäältä johdatteluksi kasvatustieteen ja kasvatuksen filosofisten perusteiden analyysiin lähtökohtana ajatus, että kasvatustiede ja kasvatus voidaan rakentaa pitävälle filosofiselle perustalle. Toisaalta Hirsjärven teos voidaan ymmärtää reaktioksi kasvatustieteemme nykyisiin ongelmiin. Tekijä pyrkii täsmentämään ja selkiinnyttämään kasvatustieteellisiä ja kasvatusfilosofisia käsitteitä, joita kasvatustieteellisessä keskustelussa usein käytetään liian epämääräisesti. Kirja on tarkoitettu ensisijaisesti kasvatustieteen opiskelijoille, mutta se soveltunee yleistajuisuutensa ansiosta myös kaikille muille kasvatustieteen ja kasvatuksen filosofisista ongelmista kiinnostuneille. Teoksen ensimmäisessä osassa tekijä tarkastelee kasvatustieteen ja sen filosofian sekä kasvatusfilosofian sisältöä, tehtäviä ja niiden välisiä suhteita. Toisessa osassa kirjoittaja esittelee antiikin filosofien, biologisen, kristillisen, eksistentialistisen, marxilaisen, freudilaisen, behavioristisen ja differentiaalipsykologisen ihmiskäsityksen keskeisimmät piirteet ja tekee selkoa niiden merkityksestä kasvatusajattelulle.

Mikä on sitten kasvatusfilosofian, kasvatustieteen ja sen filosofian välinen suhde? Hirsjärvi hyväksyy käsityksen, että filosofian erottaa eri- 
tyistieteistä ainoastaan sen yleisyys, eli kun erityistieteet tutkivat omaa spesifiä tutkimuskohdettaan, niin filosofia tutkii todellisuutta yleensä. Tämän ajattelutavan mukaisesti kasvatusfilosofian tehtävänä kasvatustieteen 'aputieteenä' on hänen mukaansa "kasvatus- ja opetustapahtuman käsitteellinen, teoreettinen analyysi, kasvatustoimintaan liittyvien perusteiden ja argumenttien kriittinen analyysi ja toimintaan kytkeytyvien ongelmien hahmottaminen ja vaihtoehtoisten ratkaisujen esittäminen näihin ongelmiin". Hirsjärvi on sitä mieltä, että kasvatustieteen filosofian tehtävänä on löytää kasvatustieteelliselle tutkimukselle pitävät ontologiset, tieto- ja arvoteoreettiset perusteet, joiden avulla harjoitettava kasvatustieteellinen tutkimus voidaan oikeuttaa. Tarkkaa eroa kasvatusfilosofian ja kasvatustieteen filosofian välillä ei kuitenkaan voida tehdä, sillä esim. kasvatustieteellisessä tutkimuksessa sovellettavien käsitteiden ja metodien filosofinen analyysi on juuri sitä, mitä Hirsjärvi tarkoittaa käsitteellä kasvatusfilosofia.

Käsitys, että kasvatusfilosofian tehtävänä on määritellä kasvatustieteelliselle tutkimukselle ja kasvatukselle pitävät ontologiset, tieto- ja arvoteoreettiset perusteet ja myös oikeuttaa ne filosofisesti ei ole kuitenkaan ongelmaton. Ensiksikin on pragmaattinen välttämättömyys, että kasvatustieteellinen tutkimus aina perustuu joillekin ontologisille, tieto- ja arvoteoreettisille ennakkoedellytyksille riippumatta siitä, ovatko tutkijat itse tietoisia niistä ja kykenevätkö he oikeuttamaan ne filosofisesti. Esimerkiksi positivistisen lähestymistavan omaksuneet kasvatustieteilijät tuskin muuttavat käsityksiään siitä, miten kasvatustieteellistä tutkimusta tulee harjoittaa, vaikka kykenisimme osoittamaan, että heidän tutkimuskäytäntönsä perustuu kyseenalaisille filosofisille oletuksille. Tämän lähestymistavan omaksuneet tutkijat katsovat näet, että on periaatteessa yhdentekevää, mille filosofisille oletuksille heidän tutkimuskäytäntönsä perustuu, koska ne eivät heidän mukaansa vaikuta heidän tutkimukseensa. He ainoastaan kuvailevat ja selittävät kasvatustieteellisiä ilmiöitä empiiristen tosiseikkojen valossa.

Toiseksi esim. monet niistä arvoista, joille kasvatustieteellinen tutkimus kulttuurissamme perustuu ovat luonteeltaan sellaisia, ettemme voi rationaalisesti valita niistä, koska ne on 'sisäänrakennettu' siihen perspektiiviin, josta tarkastelemme kasvatusilmiöitä länsimaisesta kasvatustraditiosta käsin. Esimerkiksi kouluopetukselle ominainen atomistinen käsitys tiedosta toisistaan riippumattomien tosiseikkojen joukkona, joiden luetteleminen tai soveltaminen on 'tietämistä' on tuskin rationaalisen valinnan tuloksena syntynyt käsitys tiedon arvosta ja merkityksestä. Tämä käsitys sisältyy näet implisiittisesti siihen empiristiseen, atomisoivaan tapaan lähestyä kasvatusilmiöitä, jo$\mathrm{ka}$ on ominaista vallitsevalle kasvatustieteelliselle paradigmalle. Kasvatustieteellisen tutkimuksen ja kasvatuksen perustana olevat arvot ja niiden filosofinen perustelu ovat siten väistämättä riippuvaisia sekä oman kulttuurimme kasvatuksellisista arvoista ja normeista että tutkijoiden omaksumista filosofisista teorioista.

Hirsjärvi esittelee kirjassaan tieteellisen selittämisen perustyypit kasvatustieteessä, mutta niin suppeasti, että tieteenfilosofiaan perehtymättömän on vaikea saada kunnon käsitystä niistä ja niiden soveltamiseen kasvatustieteellisessä tutkimuksessa liittyvistä rajoituksista. Hirsjärven mukaan kasvatustieteellinen tutkimus on sekä idiografista että nomoneettista, koska kasvatustieteilijät eivät tyydy pelkästään yksityisiä tapauksia koskevaan tietoon, vaan pyrkivät löytämään yleisiä lainalaisuuksia ja invariansseja, joiden avulla kasvatusilmiöitä selitetään. Tekijä hyväksyy siten käsityksen, että mm. Carl G. Hempelin tunnetuksi tekemää 'peittävän lain mallia' (the Covering Law Model) voidaan soveltaa myös kasvatustieteellisessä tutkimuksessa. Tämän selitysmallin mukaan selitämme selitettävän tapahtuman (explanandum) esiintymisen käyttämällä selitysperusteina (explanans) yleisiä lakeja ja välttämättömiä alkuehtoja, jotka selittävät miksi ko. tapahtuma esiintyi. Hirsjärvi ei kuitenkaan pohdi kirjassaan niitä periaatteellisia ongelmia, jotka liittyvät ko. selitysmallin soveltamiseen ihmistieteissä. 'Peittävän lain mallin' vastustajat (esim. William H. Dray ja G.H. von Wright) katsovat, että sitä ei voida soveltaa ihmistieteellisessä tutkimuksessa mm. siksi, että toimijoiden tekojen ja heidän tekojensa selitysperusteiden (intentioiden ja motiivitaustan) välinen suhde on käsitteellinen tai looginen eikä empiirinen, kuten ko. selitysmalli edellyttää. Esimerkiksi kasvatustieteilijät tutkivat inhimillisiä tekoja, joiden ymmärtäminen ja selittäminen ei edellytä niiden subsumoimista yleisten lakien alle.

Hirsjärvi ei positivistisen, dialektisen ja fenomenologishermeneuttisen lähestymistavan välisiä eroja selvitellessään koe kasvatustieteilijöiden omaksumaa positivistista lähestymistapaa miksikään todelliseksi ongelmaksi. Tämä on sikäli yllättävää, että ei liene liioiteltua sanoa, että kasvatustieteen nykyiset ongelmat johtuvat ainakin osittain juuri kasvatustieteilijöiden omaksumasta positivistisesta lähestymistavasta, joka perustuu mm. käsitykselle, että kasvatustodellisuus on yksinkertaisesti sitä, mitä tutkijan variaabelit mittaavat, eli he eivät näe metsää puilta. 
Eksakti metodologiakaan ei sinänsä auta tutkijaa ymmärtämään syvällisemmin kasvatusilmiöitä, sillä menetelmät tuottavat mielenkiintoisia tuloksia vain jos hän hallitsee tutkittavan ilmiön teoreettisesti ja osaa esittää oikeita kysymyksiä, jotka määräävät sen, mitä vastauksia hän voi etsiä tutkimuksessaan.

Hirsjärven kirja on kokonaisuutena selkeästi jäsennelty ja kirjoitettu johdatus kasvatusfilosofian ja kasvatustieteen keskeisiin filosofisiin ongelmiin. Tekijä keskittyy teoksessaan ensisijaisesti esittelemään kasvatusfilosofian, kasvatustieteen ja sen filosofian käsitteitä sekä ontologisia, tieto- ja arvoteoreettisia perusteita. Johdannoksi tarkoitetussa oppikirjassa tämä on tietenkin täysin paikallaan, mutta olisin silti kaivannut hieman problematisoivempaa otetta aiheiden käsittelyssä. Nyt lukija saa mielestäni liian 'siloitellun' kuvan kasvatustieteen ja kasvatusajattelun filosofisista ongelmista. Kirjasta saa näet helposti käsityksen, että tärkeimmät kasvatusfilosofiset ongelmat on jo periaatteessa ratkaistu, ja että kasvatustieteellisessä tutkimuksessa ei esiinny mitään sellaisia fundamentaalisia filosofisia ongelmia, joiden ratkaiseminen edellyttäisi esim. nykyisen tutkimuskäytännön tieteenfilosofisten perusteiden kyseenalaistamista. Hirsjärven teos on tärkeä aikuiskasvattajalle kahdella tavalla: se antaa aikuiskasvattajalle tiiviin yleiskatsauksen kasvatusfilosofian suuntauksiin ja toisaalta saa hänet kenties pohtimaan omassa kasvatustoiminnassaan esille tulevia kasvatusfilosofisia ongelmia.

Heikki T. Saari 